\title{
FACTORS CONTRIBUTING TO SMES FAILURE IN MEETING SUPPLIER PERFORMANCE STANDARDS
}

\author{
Louise van SCHEERS \\ University of South Africa, College of Economic and Management Sciences \\ e-mail: vscheml@unisa.ac.za
}

\begin{abstract}
This study sought to determine the factors that contribute to the failure of small and medium enterprises (SMEs) in meeting supplier performance standards. Suppliers are faced with the challenge of SMEs failing to meet supplier performance standards because they rely on these providers of products and services, mainly SMEs, for their operations and to ultimately achieve their mandate. The researchers were able to establish the main factors contributing to SME failure in meeting supplier performance standards. These are as follows: unclear specifications and terms of references from suppliers; insufficient information provided to SME suppliers to ensure understanding of requirements; insufficient feedback and support; no support of SME suppliers based on their Black Economic Empowerment (BEE) status; limited or no use of business support programs by SME suppliers; and external factors such as access to finance, changes in the economy, and location.
\end{abstract}

Keywords: SME failure, supplier performance standards, BEE status.

\section{Introduction}

One of the significant characteristics of a flourishing and growing economy is a booming and blooming small and medium enterprises (SMEs) sector (Fida, 2008). According to Fida (2008), SMEs play an important role in the development of a country. They contribute to economic development by creating employment for the growing labor force in rural and urban areas; they also generate income, thereby providing desirable sustainability and innovation for the economy as a whole and eventually, leading to the reduction of poverty. Maas and Herrington (2006) confirm this as they state that SMEs are seen as a significant component of the solution to South Africa's development issues, which include poverty, income inequality, and unemployment. A recent study conducted by Abor and Quartey (2010) estimates that 91 per cent of formal business entities in South Africa are SMEs, and these SMEs contribute between 51 and 57 per cent of the Gross Domestic Product and provide about 61 per cent employment; Van Scheers (2011) also confirms these statistics.

In view of the significant potential SMEs hold for the South African economy, the government and other role players have taken initiatives to support and develop SMEs in a bid to realize their suc- cess and potential (e.g., The Banking Association South Africa). The Banking Association South Africa and member banks are committed to SME development and offer support through stakeholder engagement, and involvement or ownership of several initiatives. Other initiatives described by Falkena, Abedian, von Blottnitz, Coovadia, Davel, Madungandaba, Masilela, and Rees (2006) that promote the development of SMEs include the current framework of SME support and development in South Africa, which comprises the following:

- The White Paper on promotion of small business (South Africa. Department of Trade and Industries. 1995), which sets out the government's strategy on the development and promotion of small business in South Africa.

- The Centre for Small Business Promotion has also been established by the government with the goals of creating an enabling environment for the growth and expansion of SMEs and of developing and supporting the institutions involved in delivering support services to SMEs.

- Khula Enterprise Finance has the mandate of improving the SME sector's access to finance, primarily through the provision of "wholesale finance" or guarantees to retail financial intermediaries, which, in turn, finance the SME sector. 
- There are other various national and official initiatives on SME promotion by the parliamentary subcommittees; the Banking Council South Africa's position papers; and various Department of Trade and Industry (DTI) programs also facilitated by its agencies such as Small Enterprise Development Agency (SEDA), Gauteng Enterprice Propeller (GEP), Industrial Development Corporation (IDC), International Trade Administration Commision (ITAC) of South Africa and many others.

These initiatives highlight the significant role played by SMEs in the economy of South Africa and therefore the need for a focused and structured approach in ensuring their sustainability. Despite their economic significance and the support and development they receive, statistics indicate that 75 per cent of new SMEs created in South Africa fail within the first two years of operation (Von Broembsen, Wood, \& Harrington, 2005). Von Broembsen et al. (2005) argue that the probability of a new SME surviving beyond 42 months and becoming an established firm is less likely in South Africa than in any other Global Entrepreneurship Monitor participating countries. Baard (2009) concurs with the above author as they argue that despite the dynamics of the small business sector, SMEs face high failure rates in the first three years of existence. Baard (2009) further argues that in South Africa, this failure rate is somewhere between 70 and 80 per cent, costing the South African economy millions.

The significant role that SMEs play in the South African economy cannot be ignored. Van Scheers (2011) argues that, although there is recognition of the important role they play in the South African economy, their development, growth, and sustainability are largely constrained by a number of factors. SME businesses are created to foster economic growth and development in the economy (Gibb, 2006).

This study is about determining the factors contributing to SME failure in meeting supplier performance standards. The study will also establish whether there is a link between SMEs not meeting supplier performance standards for delivering products and services and their businesses failing and having to close down the operations. The result of the study will be used to recommend a solution that can address this problem. The results will also inform the supplier on how to assist SMEs to meet its supplier performance standards as part of its supplier development strategy. The aim and objective of this study is to determine the factors contributing to SME failure in meeting supplier performance standards.

\section{Research methodology}

Secondary and primary sources were used to gather information and analyze the managerial skills of small business owners. The main sources of secondary sources were journals, articles, press reports, books, and research studies. The first population identified above, SME suppliers, was so large (706) that it was impractical and uneconomical to involve all of them in the research. Purposive sampling was used to draw a sample of 30 participants. For the second population identified, the supply chain management practitioners, the whole population was used because it was a very small population of 3 . This population was selected because these are employees who are directly and constantly in contact with SME suppliers. In the last population identified, the senior managers, purposive sampling was used to select the managers to be involved in the research. Seven business unit managers (end users) were interviewed to gather information pertaining to the business performance of the SME suppliers. All the data were collected between October 28 and November 4, 2013 from SME suppliers, supply chain management practitioners, and end users. No data were accepted before or after these dates to ensure consistency of results.

\section{$3 \quad$ Literature review - factors contributing to SME failure}

There are a lot of different enterprises in communities; many are small businesses. Sometimes one person owns and runs them; sometimes they are a family business; other businesses are owned and run by partners who are not family relations. People usually decide to set up a small business to earn an income from producing and selling prod- 
ucts or delivering services to individuals or other businesses. To earn an income from a small business, the enterprise has to run at a profit; that is, some money should be left over for the business owner once all the costs of making the product or delivering a service have been met (Maisto, 2012). In their definition of SME, Gouanlong and Tsapi (2012) allude to the fact that, despite its importance, there is no generally agreed or universally applicable definition for SMEs. Numerous factors related to a given socioeconomic environment influence the definition of SMEs. They argue that the most widely used framework in South Africa is the definition of the National Small Business Act. A supplier is defined by Lasser (2007) as a person or company that provides goods/products and/or services to other companies as one of the contributors to the development process on the way to the ultimate customer. Lasser says a supplier could produce and deliver raw materials, partially assembled components, custom parts, or any consumable supplies and labor, consulting, or management services. Suppliers are therefore expected to meet all the supplier performance standards on products and services that they supply.

According to Lambert and Pohlen (2008, p.11), supplier performance standards are the observable behaviors and actions that explain how the products and/or services are to be delivered, plus the results that are expected for satisfactory performance. Lambert argues that the purpose of performance standards is to communicate expectations to suppliers of how the products and services should be provided; it provides the supplier with specific performance expectations for each delivery of a product and/or service. Supplier performance standards are terms of reference and specifications that define characteristics of a product and/or services such as levels of quality and quantities, performance, delivery dates, technical experience, and many other requirements that a supplier must meet in the provision of products and services that the supplier procures.

Through constant monitoring and evaluation, suppliers have established that most SMEs fail to meet these standards. This includes specifications relating to levels of quality and quantities, performance, delivery dates, technical experience, and many others. As a result of this failure to meet performance stand- ards, suppliers are forced to procure from large businesses because of their capacity and experience in avoiding supply disruption, and to ensure supply continuity and optimize supplier performance. This is, however, not desirable as it is not in line with suppliers' procurement policy, which prescribes that procurement be biased toward SMEs.

In light of this, it is important that a study be conducted to determine the root cause of SME failure in meeting supplier performance standards. The study will also recommend solutions to address these issues, as it is critical that SMEs become more profitable and sustainable due to their vital contribution to the South African economy.

Failure is an absence of success. Like success, it can only be understood in this context in relation to expectations and goals that the supplier wants to achieve in its dealings with its suppliers. Failure usually results if expectations are not met, and thus this concept of failure may mean different things to different people. Starting and operating a small business includes a possibility of success as well as failure. Because of their small size, a simple management mistake is likely to lead to certain death of an SME, and hence provides no opportunity to learn from its past mistakes. Lack of planning, improper financing and poor management have been posited as the main causes of failure of SMEs (Longenecker, Petty, Moore, \& Palich, 2006). Lack of credit has also been identified as one of the most serious constraints facing SMEs and hindering their development (Oketch, 2007). The National Small Business Act of 1996 paved the way for the launch of a range of entirely new institutions within the DTI group, including the Ntsika Enterprise Promotion Agency, and Khula Enterprise Finance. Ntsika, which has now been merged under the SEDA, was a government agency whose mission was to render efficient and effective promotion and support service to SMEs in order to contribute to equitable economic growth in South Africa and minimize SME failure.

\section{Research findings - SME Suppliers' Demographics}

The gathering of information on demographics was aimed at assessing the SME suppliers' demographics 
such as classification of their business in terms of size, the number of people they employ, the nature of their business, as well as the number of years they have been in business.. Most of the respondents $(73 \%)$ were from specific groups of suppliers. The majority (90\%) of SME businesses employ less than 50 people and the minority (only 10\%) employ more than 50 to about 200 people.

\section{Compliance requirements}

The information on compliance requirements was to assess whether the respondents have tax clearance and Black Economic Empowerment (BEE) certificates. These are standard compliance conditions suppliers require from anyone who supplies them with products and services. This is in line with legislative requirements for all the public sector companies. In this section, the respondent had to indicate: whether their tax clearance certificate was always readily available and valid at any given time, whether BEE certificates helped to give them more busi- ness opportunities, and when requested to complete and submit these certificates, are they able to do so at any given time.

A very large proportion of respondents (97\%) indicated that their tax clearance certificates are always readily available and valid at any given time. The same proportion indicated that when requested to complete and submit tax clearance certificate and BEE requirements, they will be able to do so. Only 30\% indicated that their BEE requirements helped them to get business opportunities as indicated in Fig. 1. The literature has shown that BEE requirements are government policy, and that many SMEs feel weighed down by these requirements that are costly to implement, but offer few benefits. There was widespread dissatisfaction among all the firms, including Black-owned businesses.

This statement is confirmed by the small percentage $(30 \%)$ of SMEs, which indicated that the BEE requirements help to give them more business opportunities, as reflected in Fig. 1.

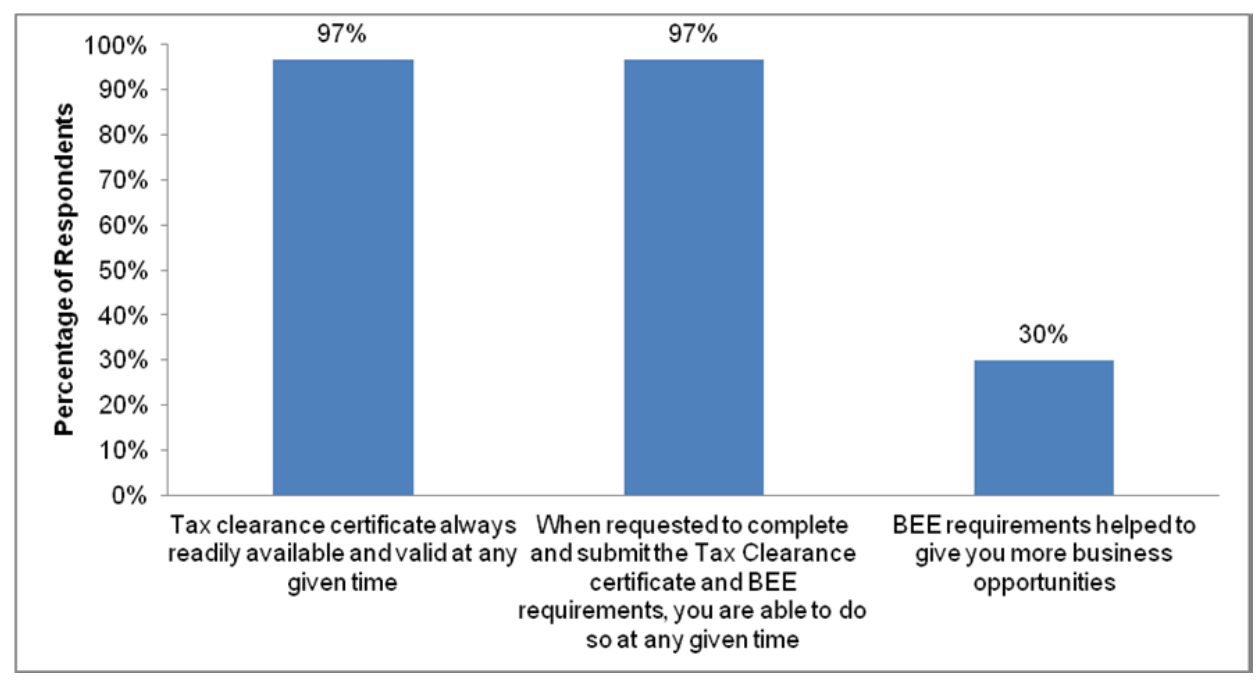

Figure 1. The respondents' indication of compliance with requirements

Fig. 1 shows that the majority of the respondents have BEE and tax clearance certificates readily available at any given time on the supplier's request during the procurement process. However, Fig. 1 also shows that this BEE certificate does not help to give them more business opportunities; this is indicated by only $30 \%$ of respondents hinting that their BEE requirements helped them to get business opportunities. The above result could also be linked to the argument made in the literature review about the SMEs' widespread dissatisfaction with Broad-Based Black Economic Empowerment (BBBEE) requirements that are costly to implement, but offer few benefits. It was argued that, despite some 57\% having accreditation, this comes with annual costs, is administratively burdensome, and is not balanced by enhanced access to procurement opportunities. 
mance standards. The respondents were asked specific questions relating to specific areas of the sup-

The purpose of this section is to establish the real plier performance standards listed in Tables 1 and 2.

causes of SME failure in meeting supplier perfor-

Table 1. Results for supplier performance standards

\begin{tabular}{|l|c|c|c|c|c|c|}
\hline \multicolumn{3}{|c|}{ One-sample statistics } & \multicolumn{3}{c|}{$\begin{array}{c}\text { One-sample test against } \\
\text { the midpoint of the scale } \\
\text { (3) }\end{array}$} \\
\hline & $\mathrm{N}$ & Mean & $\begin{array}{c}\text { Std. De- } \\
\text { viation }\end{array}$ & $\mathrm{t}$ & $\mathrm{df}$ & $\begin{array}{c}p- \\
\text { value }\end{array}$ \\
\hline $\begin{array}{l}\text { You are able to meet supplier quality standards } \\
\text { and requirements }\end{array}$ & $\mathbf{2 8}$ & $\mathbf{4 . 6 1}$ & $\mathbf{0 . 8 3 2}$ & $\mathbf{1 0 . 2 2 5}$ & $\mathbf{2 7}$ & $\mathbf{. 0 0 0}$ \\
\hline $\begin{array}{l}\text { You have the capacity to deliver all products and } \\
\text { services on time }\end{array}$ & $\mathbf{3 0}$ & $\mathbf{4 . 4 7}$ & $\mathbf{1 . 0 4 2}$ & $\mathbf{7 . 7 1 2}$ & $\mathbf{2 9}$ & $\mathbf{. 0 0 0}$ \\
\hline $\begin{array}{l}\text { Supplier sets unrealistic delivery dates and re- } \\
\text { quirements }\end{array}$ & $\mathbf{3 0}$ & $\mathbf{3 . 7 3}$ & $\mathbf{1 . 4 8 4}$ & $\mathbf{2 . 7 0 7}$ & $\mathbf{2 9}$ & $\mathbf{. 0 1 1}$ \\
\hline $\begin{array}{l}\text { Supplier adheres to the principle of fairness and } \\
\text { transparency }\end{array}$ & 30 & 3.37 & 1.066 & 1.884 & 29 & .070 \\
\hline $\begin{array}{l}\text { Supplier's terms of reference and specifications on } \\
\text { tenders and quotations are always clear }\end{array}$ & 30 & 3.17 & 1.663 & 0.549 & 29 & .587 \\
\hline $\begin{array}{l}\text { Supplier provides sufficient information to ensure } \\
\text { you understand the requirements }\end{array}$ & 30 & 3.00 & 1.702 & 0.000 & 29 & 1.000 \\
\hline $\begin{array}{l}\text { You get more support from supplier based on your } \\
\text { BEE status }\end{array}$ & 29 & 2.55 & 1.639 & 1.473 & 28 & .152 \\
\hline $\begin{array}{l}\text { Supplier requests for tender and quotation appear bi- } \\
\text { ased }\end{array}$ & 30 & 2.53 & 1.042 & 2.454 & 29 & .020 \\
\hline $\begin{array}{l}\text { You always receive sufficient feedback and support } \\
\text { from supplier regarding your performance }\end{array}$ & 30 & 2.43 & 1.501 & 2.067 & 29 & .048 \\
\hline
\end{tabular}

In Table 1, it is indicated that the respondents agreed with the statements "High level of achievement," "You are able to meet supplier's quality standards and requirements" $($ mean $=4.61, \mathrm{p}$-value $=.000)$, "You have the capacity to deliver all products and services on time" $($ mean $=4.47$, p-value $=.000)$, and "Supplier sets unrealistic delivery dates and requirements" $($ mean $=3.73$, p-value $=.011)$. These statements had mean ratings greater than the midpoint of the scale and p-values of the one-sample t-test less than .05. This implies that the null hypothesis is rejected in favor of the alternative hypothesis at 5\% significance level.

The respondents neither agreed nor disagreed with the statements: "Supplier adheres to the principle of fairness and transparency." This is because the p-values of the one-sample t-test against the midpoint of the scale were greater than .05 . On the other hand, the respondents disagreed with the statements: "Supplier terms of reference and specifications on tenders and quotations are always clear" (mean= 3.17 , p-value $=.587$ ), "Supplier provides sufficient information to ensure you understand the requirements," "You get more support from supplier based on your BEE status" $($ mean $=2.53$, p-value $=.020)$, and "You always receive sufficient feedback and support from supplier regarding your performance" $($ mean $=2.43, \mathrm{p}$-value $=.048)$. These statements had mean ratings lower than the midpoint of the scale and $\mathrm{p}$-values of the one-sample t-test less than .05 . This implies that the null hypothesis is rejected in favor of the alternative hypothesis at 5\% significance level.

Based on the responses displayed in Table 1, SME suppliers have the ability to meet supplier performance standards such as quality standards, and they have the capacity to deliver the products and services procured from them. But not many of them agree that supplier sets up unrealistic delivery dates and requirements. 


\section{$7 \quad$ Impacts on delivery}

The purpose of this section is to assess the areas that impact on the respondent's ability to deliver and meet the supplier performance standards. This was to check whether the factors contributing to SME failure in meeting the supplier performance standards have any link to those factors contributing to SME failure in the literature. One-sample $t$-tests were also carried out to assess the level of agreement with impacts on delivery. The null hypothesis for each statement was that the respondents neither agree nor disagree with the statement (mean $=3$ ) and the alternative hypothesis was that the respondents either agree or disagree. The results are shown in Table 2.

Table 2. Impacts on delivery results

\begin{tabular}{|l|c|c|c|c|c|c|}
\hline \multicolumn{1}{|c|}{ One-sample statistics } & & & & \multicolumn{2}{c|}{$\begin{array}{c}\text { One-sample test against the } \\
\text { midpoint of the scale (3) }\end{array}$} \\
\hline & $\mathbf{N}$ & Mean & $\begin{array}{c}\text { Std. de- } \\
\text { viation }\end{array}$ & $\mathbf{t}$ & $\mathbf{d f}$ & p-value \\
\hline $\begin{array}{l}\text { You have the relevant technology, i.e., computer, } \\
\text { fax, and printer to be able to meet supplier re- } \\
\text { quirements }\end{array}$ & 30 & 4.67 & .661 & 13.813 & 29 & .000 \\
\hline Supplier pays your invoices in time & 30 & 4.63 & .490 & 18.252 & 29 & .000 \\
\hline $\begin{array}{l}\text { You are aware of platforms to market your busi- } \\
\text { ness }\end{array}$ & 30 & 4.57 & 1.040 & 8.251 & 29 & .000 \\
\hline $\begin{array}{l}\text { Your management skills and experience enable } \\
\text { you to meet supplier performance requirements }\end{array}$ & 30 & 4.57 & .935 & 9.175 & 29 & .000 \\
\hline You have the tools to market your business & 30 & 4.53 & 1.042 & 8.063 & 29 & .000 \\
\hline Changes in the economy will affect your cash flow & 30 & 4.37 & 1.299 & 5.761 & 29 & .000 \\
\hline $\begin{array}{l}\text { Access to finance affects your ability to meet sup- } \\
\text { plier tender and quotation requirements }\end{array}$ & 30 & 4.33 & 1.308 & 4.611 & 29 & .001 \\
\hline $\begin{array}{l}\text { Your business location impacts on your delivery } \\
\text { schedules and performance }\end{array}$ & 30 & 4.29 & 1.400 & .964 & 29 & .003 \\
\hline
\end{tabular}

The results in Table 2 reveal that the respondents agreed significantly with all the following statements since the mean ratings were all greater than the midpoint of the scale (3) and the $p$-values less than .05 .

The majority of the respondents (see Table 2) indicate that they have the necessary tools to meet the supplier performance standards, that is, the relevant technology like computers, fax, and printers.

They have management skills and experience to enable them to meet supplier performance standards; they are aware of platforms to market their businesses; they have the tools to market their businesses and the supplier pays their invoices on time.

\section{Reasons SMEs fail to meet supplier performance standards}

The purpose of this section is to get the views of end users and practitioners on the reasons SME suppliers fail to meet the supplier performance standards. End users were asked several questions, as listed below.

- Are you confident of your process of communication with SME suppliers?

The first quest was to check whether they were confident with the supplier's process of communication with SME suppliers. This was based on the requirements of the supplier performance standards, where the end user communicates his or her expectations to the supplier. 


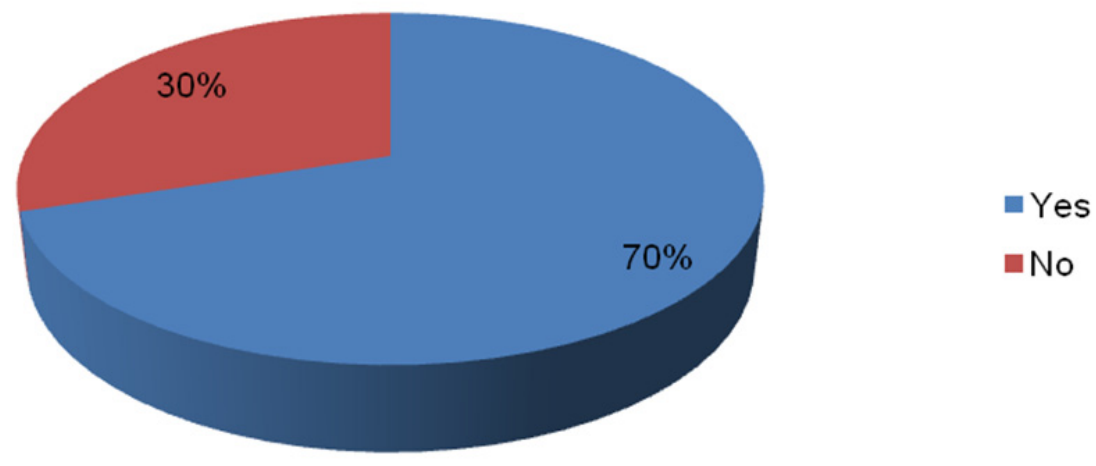

Figure 2. Evaluation of confidence in supplier's process of communication with SME suppliers

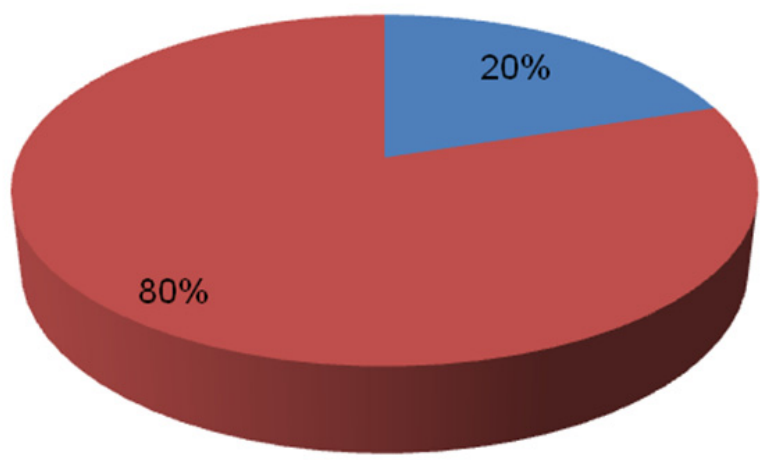

- Confident

not Confident

Figure 3. Evaluation of confidence in systems enabling SME suppliers to meet supplier performance standards

The majority of the respondents $(70 \%)$ were confident with the supplier's process of communication with SME suppliers while the remaining 30\% were not. The results are shown in Fig. 2.

Fig. 2 represents a big split, the majority being confident with supplier's process of communication with SME suppliers.

- Are you confident that the systems enable SME suppliers to meet the supplier performance standards?

Four in every five respondents were not confident that the supplier's systems enable SME suppliers to meet the supplier performance standards.

Figure 3 indicates that $80 \%$ respondents are not confident that the supplier systems enable SME suppliers to meet supplier performance standards. This is indeed a high number and calls for more attention in this particular area. This will be discussed in detail at a later stage.

- How supplier makes sure that SME suppliers are paid on time

The previous research studies argue that two years ago the cabinet launched regulations that require government departments to pay contractors within 30 days. However, many small businesses that do work for the government still do not get paid on time. The researcher wanted to check whether that was the case with suppliers as late payment has been argued as one of the factors contributing to SME failure.

Seven out of ten respondents indicated that they sign off the request for payment as soon as they get the delivery. It was also mentioned that the payment of SME suppliers was set as a key performance indicator (KPI) and thus the supplier employees have to do it. 
Table 3. How the supplier makes sure that suppliers are paid on time

\begin{tabular}{|l|c|c|}
\hline \multicolumn{1}{|c|}{ How do you make sure that SME suppliers are paid on time? } & Frequency & Percentage \\
\hline Sign off finance requests on time & 7 & $70 \%$ \\
\hline Create weekly payment reports and ensure all outstanding invoices are paid & 1 & $10 \%$ \\
\hline Was specified as a KPI and hence we do it & 1 & $10 \%$ \\
\hline We make sure they are paid within 15 days & 1 & $10 \%$ \\
\hline
\end{tabular}

Table 3 indicates that a majority of the respondents sign off on time on completion of product or service delivery to ensure that SME suppliers are paid on time. This is indicated by the $70 \%$ response. They also follow up on outstanding invoices, as it is part of their key performance indicators.

\section{Conclusion}

The research objective for this study was to determine the factors that contribute to SME failure in meeting supplier standards. The researcher's problem is that SME failure negatively impacts on a supplier's ability to provide its products and services adequately. If the problem persisted, the effect could be that:

- the supplier may not be able to fully meet its mandate and objective in terms of operations,

- the supplier may not be able to support and develop SMEs,

- SMEs would not receive the support they need from the supplier,

- the supplier may be forced to procure only from large businesses, thereby contravening its procurement policy,

- SMEs might have to close down because of the business they are losing.

The researcher was able to establish the main factors contributing to SME failure in meeting the supplier performance standards. These are unclear specifications and terms of references from the supplier; insufficient information provided to SME suppliers to ensure understanding of requirements; insufficient feedback and support from the supplier regarding supplier performance; no support of SME suppliers based on their BEE status; limited or no use of business support programs by SME suppliers; and exter- nal factors such as access to finance, changes in the economy, and location.

Solutions were then formulated to eliminate the above factors, which hamper SMEs from meeting the supplier performance standards. At face value, it would seem that the factors contributing to this failure would be on the part of the SMEs. The research has, however, highlighted critical flaws on the side of the supplier, requiring material change to the operating model in order to address these factors.

This research will enable the supplier to develop a much more focused strategy, not only to provide a platform for engagement with suppliers, but also one that will enable supplier end users to have a better understanding of supplier's needs and equip them to develop clearer specifications and terms of reference for use by suppliers.

Continuous evaluation may be necessary to ensure that as supplier's needs become more complex in providing supplier products and services in line with the mandate, supplier end users are well equipped to better articulate specifications and terms of references in a way that can be easily understood by the suppliers. This can be followed up with a continuous assessment of the process of support and feedback to SME suppliers.

\section{Acknowledgment}

The author acknowledges the contribution of S. Rampa's MBA dissertation: Determining the factors contributing to Small and Medium Enterprises' (SMEs) failure in meeting the Small Enterprise Development Agency (SEDA) Supplier Performance Standards, November 2013 on which this article is based. 


\section{References}

[1] Abor, J., Quartey, P., 2010. Issues in SME development in Ghana and South Africa. International Research Journal of Finance and Economics. Issue 39. [online] Available at: http://www.eurojournals.com/irjfe_39_15.pdf.

[2] Angerhofer, B., Angelides, M., 2006. A model and a performance measurement system for collaborative supply chains. Decision Support Systems, 42(1), pp.283-292.

[3] Ary, D., Jacobs, L.C., Razavich, A., 2007. Introduction to research in education. Fort Worth: Harcourt Brace College Publications.

[4] Baard, V.C., 2009. Interactive information consulting systems for South African small businesses. Peer Reviewed Article. The South African Journal of Information Management. 6(2) June 2009.

[5] Babbie, E., Mouton, J., Vorster, P., Prozesky, B., 2009. The practice of social research. South African Fifth Edition. Cape Town: Oxford University.

[6] Berry, B., 2010. Lending confusion leaves SME without finance, [online] Available at: http://www.construction-manager.co.uk/news/ lending-confusion-leaves-smes-unable-securefinanc/

[7] Bowler, A., Dawood, M.S., Page, S., 2007. Entrepreneurship and small business management. Pretoria: Juta.

[8] Brown, K.V., 2001. The determinants of crime in South Africa. The South African Journal of Economics, 69(2).

[9] Ensor, L., 2013. Seda to focus on small and medium businesses to create jobs. Business Day. 25 September 2013.

[10] Cassar, G., 2007. Money, money, money? A longitudinal investigation of entrepreneur career reasons, growth preferences and achieved growth, Entrepreneurship and Regional Development, 19 (1), pp.89-107.

[11] Chimucheka, T., Rungani, C., 2011. The impact of inaccessibility to bank finance and lack of financial management knowledge to small, medium and micro enterprises in Buffalo City Munic- ipality. South Africa: Department of Business Management, University of Fort Hare.

[12] Coco, G., 2000. On the Use of Collateral. Journal of Economic Surveys, 14( 2), pp.191-214

[13] Cooper, D.R., Schindler, P.S., 2007. Business Research Methods. (11th edition), 2011, McGraw-Hill/Irwin Paul I-Hai Lin, Professor. [online] Available at:

http://www.ipfw.edu/ lin A Core Course for M.S. Technology.

[14] Coulthard, M., Loos, J., 2007. Networking, the link in firm based entrepreneurial orientation (EO) performance model, [online] Available at: http://www.buseco.monash.edu.au/mgt/staff/cou lthard.max.

[15] Creswell, J.W., Vicki, L Clarke P., 2007. Designing and Conducting Mixed Methods Research. Thousand Oaks, CA: Sage Publications.

[16] Dahl, M.S., Sorenson, O., 2007. Home sweet home. Social capital and location choice, [online] Available at:

http://www.druid.dk/fileadmin/images/dokument er/sorenson.pdf

[17] Downing, R., 2011. SMEs face tough growth challenges in SA. Business Day, 6 August 2012, 13:32. [online] Available at:

http://www.bdlive.co.za/articles/2011/11/22/sme s-face-tough-growth-challenges-in-sa-report

[18] Driscoll, D.L., Appiah-Yeboah, A., Salib, P., Rupert, D.J., 2007. Merging Qualitative and Quantitative Data in Mixed Methods Research: How To and Why Not. Sage: Thousand Oaks.

[19] Ehlers, T., Lazenby, K., 2007. An Investigation into the Obstacles to Youth Entrepreneurship. Department of Business Management, University of Fort Hare in South Africa.

[20] Ensor, Linda. 2012. Incubators' new buzzwords in enterprise promotion. Business Day, February 9.

[21] Falkena, H., Abedian, I., von Blottnitz, M., Coovadia, C., Davel, G., Madungandaba, J., Masilela, E., Rees, S. SME's access to finance in South Africa. A supply-side regulatory review. [online] Available at:

http:/www.treasury.gov.za/publications/other/A ccess $\% 20$ to $\% 20$ Finance $\% 20$ in $\% 20$ South $\% 20$ Af 
rica $\% 20-\% 20 \mathrm{~A} \% 20$ Supply-Side $\% 20$ Regulatory \%20Review.pdf

[22] Fatoki, O., Akinwumi, O, 2010. Which New Small and Medium Enterprises in South Africa Have Access to Bank Credit?

[23] Fatoki, O., Garwe, D., 2010. Obstacles to the growth of new SMEs in South Africa: a principal component analysis approach, [online] Available at:

http://www.academicjournals.org/AJBM/PDF/p df2010/May/Olawale\%20and\%20Garwe.pdf

[24] Fida, Bashir Ahmad., 2008. The Importance of Small and Medium Enterprises (SMEs) in Economic Development. The Free Library, [online] Available at:

http://www.thefreelibrary.com/The Importance of Small and Medium Enterprises (SMEs) in Economic...-a01073924138.

[25] FinMark, 2010. FinScope: South Africa Small Business Survey 2010. FinMark Trust. [Online]. Available from: http://www.finmarktrust.org.za/pages/FocusAreas/Small,-Micro-and-Medium-Enterprises .aspx?random.

[26] Gibb, A., 2006. Entrepreneurship and Enterprise Development in Transition Economies Policy Guidelines and Recommendations. OECD and UNIDO.

[27] Lasser (2007) Supplier Definition. Small Business Network, Inc. [Online] Available from: http://www.askjim.biz/answers/supplierdefinition_6369.php.

[28] Lambert, D., Pohlen, T., 2008. Supply Chain Metrics. The International Journal of Logistics Management, 13(1), pp.1-19.

[29] Longenecker, J.G., Petty, C.W., Moore, J.W., Palich, L.E., 2006. Small Business Management, an Entrepreneurial Emphasis. London: Thomson South Western.
[30] Maas, G., Herrington, M., 2006. Global Entrepreneurship Monitor South African Report. University of Cape Town. Graduate School of Business.

[31] Maisto, G., 2012. What is an enterprise? myfuture 2012, [online] Available at:

http://www.myfuture.edu.au/The\%20Facts/Work $\% 20$ and $\% 20$ Employment/Enterprise $\% 20$ for $\% 20$ Young\%20People/What\%20is\%20enterprise.asp $\mathrm{x}$.

[32] National Small Business Act (NSB Act) of 1996.

[33] Oketch, H.O., 2007. Gender Equity. In Mullei, A. \& Bokea, A. (eds). Micro and small Enterprises in Kenya: Agenda for improving the Policy Environment. Nairobi: ICEG.

[34] Gouanlong, N.I., Tsapi, V., 2012. The procedures for strategic management of new products for small, medium and large firms in Cameroon: an exploratory study. African Journal of Marketing Management, 4(4), pp.118-129. [online] Available at:

http://www.academicjournals.org/AJMM DOI: 10.5897/AJMM11.152 ISSN 2141-2421 C2012 Academic Journals

[35] Van Scheers, L., 2011. SMEs' marketing skills challenges in South Africa. African Journal of Business Management. 5(13), pp.5048-5056. [online] Available at: http://www.academicjournals.org/AJBM

[36] South Africa. Department of Trade and Industries. 1995. The White Paper on National Strategy for the Development and Promotion of Small Business in South Africa. Notice 213 OF 1995.

[37] Von Broembsen, M., Wood, E., Herrington, M., 2005. Global entrepreneurship monitor South Africa report. [online] Available at: http://www.gsb.uct.ac.za/gsbwebb/userfiles/gem 2005.pdf [Accessed: 19 October 2007]. 